\title{
Peer Affective Factors in Peer Collaboration: Facebook- based Collaborative Writing Activity among Turkish High School EFL Learners
}

\author{
Hasan Selcuk \\ King's College London, School of Education, Communication \& Society, UK \\ hasanselcuk35@hotmail.com
}

\begin{abstract}
This paper is about an investigation into student perceptions of peer affective factors during a Facebook-based collaborative writing activity among Turkish high school EFL learners. Two groups of three students, 16-year-old EFL learners at A2 level English proficiency (CEFR), undertook an online collaborative English short story writing exercise over seven weeks using Facebook. I gathered data from focus group discussions, online one-to-one chats and online discussion threads from both groups. Although small-scale, valuable insights were obtained into peer affective factors that emerged throughout the writing exercise, and were concerned with receiving / giving praise and motivational phrases, the use of informal language and humour in writing during the exercise as well as in relation to feeling comfortable with each other. The students claimed these factors greatly aided the development of their writing skills.
\end{abstract}

Key Words: affective factors in online learning, online collaborative writing, webbased foreign language learning

\section{Introduction}

A broad definition of collaborative writing, according to Storch, is "the co-authoring of a text by two or more writers" [23, p.2]. With the rapid growth of Web 2.0 technologies, in recent years, research on classroom-based collaborative writing in an English as Foreign Language (EFL) context has shifted to online collaborative writing. Previous research on collaborative writing in an EFL context has commonly used wiki (Lund [16], Kessler [10], Miyazoe \& Anderson [19], Lin \& Yang [15], Chao \& Lo [3], Li \&Zhu [14]), weblog (Miyazoe \& Anderson [19]), and Facebook group (Bani-Hani, Al-Sobh \& Abu-Melhim [2]) as online tools. Previous research on online collaborative writing has also revealed that online tools (wiki, weblog and Facebook group) facilitated the collaborative writing process for EFL learners (Lund [16], Miyazoe \& Anderson [19], Lin \& Yang [15], Chao \& Lo [3], Bani-Hani et al [2]). Moreover, online collaborative writing showed progress in EFL learners' writing development (Kessler [10], Miyazoe \& Anderson [19], Bani-Hani et al [2]). Li \& Zhu [14] also investigated peer interaction patterns in online collaborative writing. However, no research has been conducted on how EFL learners interpret peer affective factors in online collaborative writing. To fill this gap in research, I 
undertook exploratory research to investigate students' perceptions of peer affective factors through the medium of Facebook-based collaborative writing activity among Turkish high school EFL learners. In this paper, I aim to report on this exploration of Turkish high school EFL learners' perceptions of peer affective factors during such a writing activity. This paper consists of five sections. I first introduce the paper. The second section constitutes a review of literature pertinent to peer affective factors in peer collaboration. The third section provides a methodological framework. The fourth section presents the findings and discussion and the fifth section concludes the paper, and considers implications of the study.

\section{Literature Review}

In this study, the importance of peer affective factors was observed amongst the participants during the online short story writing activity. Before outlining previous studies on peer affective factors on peer collaboration, I first draw on Vygotsky's views on affective aspects of learning. He held that cognition and affect are indistinguishably interconnected to each other, as he exemplifies in his assertion:

When we approach the problem of the interrelation between thought and language and other aspects of mind, the first question that arises is that of intellect and affect. Their separation as subjects of study is a major weakness of traditional psychology, since it makes the thought process appear as an autonomous flow of 'thoughts thinking them- selves' segregated from the fullness of life, from personal needs and interests, the inclinations and impulses of the thinker [26, p.10].

Under the Vygotskian optic, Stahl [22] viewed cognition as a social process which enabled learners to build knowledge and solve problems through group interaction. Webster's Seventh Collegiate Dictionary [18, p.15] defined 'affect' as (1): feeling, affection (2): the conscious subjective aspect of an emotion considered apart from bodily change.” According to Shroader \& Cahoy [21], affective domains comprise a learner's attitudes, emotions, interests, motivation, self-efficacy and values. Cooper [4], who has researched the role and place of empathy (which involves caring and emotions) with school teachers and their students, also emphasised the inextricable interconnection of cognition and affect contending that the two go hand in hand in learning. Cooper's work is relevant in that the groups in my study felt the need to elect a peer leader to take on a leadership and instructional role, indeed a caring role. On this point, Cooper writes that: "Affect is central to communication and the formation of relationships between people' [4, p.5].

Previous studies on collaborative writing in an EFL context have mainly centred on cognitive and linguistic aspects of learning. In what follows, I identify certain affective aspects of learning through different types of peer collaboration, such as written /oral peer feedback. Although there have been no studies on collaborative writing in an EFL context focusing on peer affective factors in peer collaboration, there are a few studies of relevance on peer feedback in this context. This is particularly the case in relation to writing (e.g. Kurt \& Atay [11], Yastibas \& Yastibas [27], Lee [13]) and in speaking as well as oral peer feedback on collaborative presentation in the study of Nguyen [20]. The studies of Kurt \& Atay [11] and 
Yastlibas \& Yastibas [27] revealed that peer feedback had a facilitating effect on EFL learners' writing anxiety. Lee [13] showed that the use of praise during peer feedback in writing activities was low, because many EFL learners appear to lack confident about their English competence, and therefore shun using it. Nguyen [19] found that the use of spoken motivational phrases when working together in pairs for a task enabled the participants to create an emotionally supportive environment where they engaged with the task as well as building a rapport, feeling comfortable and increasing their self-confidence.

Other studies focused on the dimension of peer affective factors in collaborative learning contexts outside the field of EFL highlighted trust and respect among learners in pair/group work (e.g. Dale [6]) as well as the positive effects of friendship on collaborative learning (e.g. Kutnick et al [12]; Vass [25]; Jones \& Pellegrini [9]; Hartup [8]). Moreover, the findings of Anderson \& Simpson's study [1] revealed that in online small group discussions the participants built a strong sense of community with more affective support than with online whole class discussions. I end this brief review with the powerful conclusion of Hartup [8, p.1) from his study on the effect of friendship in collaborative learning, which was that 'friends provide one another cognitive and social scaffolding'.

\section{Methodology}

In this research, I aimed to explore Turkish high school EFL learners' perceptions on peer affective factors during a Facebook-based collaborative writing activity. The focus on this aspect of this research is reflected in the following research question: How Turkish high school EFL learners interpret peer affective factors during a Facebook-based collaborative writing activity?

I decided to use a qualitative approach, as I considered this to be consistent with the foci of the research. According to Merriam [17, p.13] a qualitative approach concerns "understanding the meaning people have constructed, that is, how people make sense of the world and the experiences they have in the world".

As there was limited literature on investigating peer affective factors in peer collaboration in a context of EFL writing either in a classroom setting or online setting both in Turkey and the rest of the world, I decided to employ an exploratory study in FB group, which is an online social networking site. The study was designed as a Facebook-based collaborative writing activity. There are two underlying reasons why I chose to undertake my study through the FB group. First, the writing skills seem not to have received enough attention in English language lessons in many Turkish high schools. EFL teachers in these schools are compelled to follow the English Language Teaching (ELT) curriculum required by the Turkish Ministry of National Education [24] and have little time to spare for extended writing activities or for classroom research. This evident lack stimulated the idea of planning an online collaborative writing activity. Second, I was aware that Turkish teenagers are attracted to FB as a social networking site (SNS). As pointed out by Demirtas [6], most of the FB users in Turkey are between the age of 18 and 35. In addition to this, this author has reported that there are 18.1 million online social networking users who 
are 15 years old and above. Therefore, I decided to exercise my intervention in the aforementioned groups as I believed this would engage their interest.

As I designed this research as an exploratory study, I first undertook a pilot study prior to the main study. The pilot study had an impact on main study methodology in determining sample size, shaping the research question and framing the design of methods. Regarding the sample size, one of my colleagues working as a teacher of EFL in Turkey agreed to help me find participants after I had obtained official consent from the Provincial Directorate of National Education and the school's principal. I presented my pilot study to a class of 34 students, six participants volunteered to involve in the pilot study. Then, I asked them to form two groups of three and produce a short story in English with their group members in a FB group over four weeks. I decided to undertake the main study with a sample of two groups of three in total six participants. I found this sample size revealed rich insights and so decided to repeat the format for the main study. Conducting the pilot study helped me firm up a clear research question for guiding the main study. In the pilot study, I used three focus group discussions but I observed that some of the pilot study participants could not or did not want to express their opinions or feelings openly in front their friends. In fact, some of them chose to do so by sending private messages or chat requests through $\mathrm{FB}$. Bearing this in mind, I decided to employ online one- to-one chats as well as focus group discussions for the main study. Furthermore, anticipating that participants' narratives might not be sufficient, I therefore planned to use the participants' online discussion boards in their FB groups for the main study to give further credibility to the data.

Concerning the main study, after obtaining official consent from the Provincial Directorate of National Education and the school's principal, another colleague of mine presented my research project to their classroom and a total of six Turkish high school EFL learners in two groups of three participated in the study voluntarily over seven weeks. These six EFL learners and participants of the main study, were $10^{\text {th }}$ graders (16 years old, 4 females, 2 males) and their English level was considered as pre-intermediate, according to the CEFR (Council of Europe [5]), A2 level. For ethical considerations, these participants' real names were anonymised and pseudonyms were used instead. To draw distinction between two groups of participants, henceforth, I call the first group (Nila, Gonca \& Deniz) group A, while the second (Ali, Attila \& Selma) was named group B.

In the main study, participants in groups were asked to write a short story in English with their group members collaboratively in a FB group created only for the study. Participants were asked to undertake this writing activity outside of school hours online. During the writing activity, participants used their smartphones and/or laptops to produce their short story collaboratively. Participants were asked to meet once or twice a week in a Facebook group to produce their short story collaboratively within seven weeks. During the study, each group of participants arranged 10 meetings within seven weeks. My role as researcher in this study was as a facilitator throughout the writing activity. I decided to become a facilitator for the main study participants because as reported by some of the pilot study participants, they had difficulties in deciding on a particular topic for their short story as a group and they had spent nearly two sessions before all agreeing on what they wanted to write about. Moreover, from the pilot study I observed that until they understood what was 
required of them, they needed considerable facilitator input, although subsequently this need diminished substantially. In the light of this, I decided to provide a short story topic for the main study participants as this would save time in them getting started. I encouraged participants to work together with minimal facilitator support. I attended all 10 meetings in a FB group for both groups. I provided participants with a short story topic and gave some guidance for them to start their short story. At the beginning of the writing activity, both groups of participants felt a need to select a group leader among their group partners when the facilitator's guidance was, for the most part, withdrawn during the early stages. Concerning the election of a group leader, some participants reported that they felt a need to select someone who seemed to them confident and knowledgeable about how to chair a group discussion, was comfortable with making decisions about what to write in a session and who, in their estimation, had better English knowledge than the other group partners in the group.

At the beginning and in the middle of the writing task, the participants were mostly dependent on their group leaders' assistance and guidance. However, towards the end of the task, when group leaders gave more freedom to their group partners and as the latter's confidence developed, the role of group leaders began to diminish. In its place, individual teacher agency developed and group partners at this stage began to contribute collectively when completing the writing exercise.

In this study, I gathered data mainly from focus group discussions, online one-toone chats and FB group discussion threads from both groups.

\section{Findings and Discussion}

One of the key findings of Lee's [13] study that was concerned with peer feedback in EFL writing indicated that many participants did not feel confident about praising their peers due to lack of experience and knowledge about how to give peer feedback. In contrast to what Lee found in her study, in my study, the group leaders gave frequent praise to their group partners. As explained by the group leaders, one of the main reasons why they used praise was to increase peer collaboration during the online short story writing exercises. According to the participants of this study who received praise from group leaders, they thought that this was motivational for them in relation to writing in English. In this research, the participants considered that peer affective factors were:

- Giving praise (e.g. well done! excellent! good work!) as group leaders;

- Receiving similar comments of praise from group leaders;

- Giving motivational phrases (e.g. you're doing well, don’t give up, we're iscepi'with you) as group leaders or a group partner;

- Receiving motivational phrases such as the above from group leaders or from a group partner(s);

- Feeling comfortable with each other when undertaking the writing exercise;

- Informal language use in group discussions including terms of endearment (such as darling, honey, and love) and the use of text speak and emoticons;

- Use of humour when undertaking individual writing tasks. 
There follows an extract from a conversation of group A (Nila, Gonca \& Deniz) to provide a context for the employment of informal language use in group discussion with terms of endearment.

Nila: Hello my darlings

Gonca: Yes, my sweetheart. I'm here.

Nila: Where is Deniz?

Gonca: She'll be here in a minute. She sent me a text. She just came home from shopping with her mum.

Nila: Okay. Let's wait for her then.

Gonca: Let's listen to this song while waiting for Deniz.

https://www.youtube.com/watch?v=KUmZp8pR1uc [Amy Winehouse-

Rehab]

Deniz: Sorry being late. Here I'm my darlings. I love you

Gonca: love you

Nguyen's [20] study, which examined peer collaboration in an EFL speaking task among six pairs, revealed that some motivational phrases (e.g. “don't worry!”, "everything will be alright after all") used by the pair partners enabled them to support each other in sustaining task engagement, building a rapport, increasing selfconfidence and feeling a sense of safety when undertaking the activity. In line with the findings of Nguyen, the participants in my study claimed that such motivational phrases increased their self- confidence about writing in English as the quotation below shows:

Ali: "At a boxing match, the audience usually say some words, such as 'keep on, you can do it, don't give up now' and especially in films, after hearing these words, boxers stand up and keep fighting with their opponents. This writing exercise for me was like a boxing match. Every time I felt weak when it comes to writing in English, Selma's [the group leader] motivating words helped me gain self-confidence and keep on writing [in English]" (focus group discussion, 2).

In this study, the participants also emphasized that they felt comfortable with each other when undertaking the writing exercise. The main reason why they said they felt this way was attributed to the developing friendships among the group partners. In the study of Kutnick, Blatchford \& Baines [12], friendship among peers in a group work was found to be a foundation for building trust between group partners, the ability to communicate effectively and the capacity to resolve problems jointly with peers. One of the key findings of Dale's [6] study, albeit in the rather different context of L1 ninth-grade students, was that trust and respect among group partners in collaborative writing enabled students to feel comfortable with each other when discussing the emerging text. In my study, both groups built a comfortable and supportive environment where group partners felt relaxed with each other when undertaking their online short story writing exercise in groups as the following quotation shows:

Ali: "My group partners are my classmates and friends. I've known Attila since primary school. We're best friends. I've known Selma since the first grade in high school. Obviously, the fact that we know each other made me feel comfortable when doing this writing exercise, because I could tell them when I faced problems and sought help. They didn't judge me at all. Selma was a very good teacher and Attila was a good partner who 
supported me whenever I had difficulty writing in English. I think knowing each other is a sort of collaboration in this writing exercise" (focus group discussion 4).

Thus, in line with the findings of Dale, the outcomes of my study lend weight to the importance of the concept of peers feeling comfortable with each other during a collaborative writing process when a sense of friendship is present. Furthermore, in this study, as recounted by the participants, becoming comfortable with each other when undertaking the writing exercise enabled them to reduce the apprehension and the anxiety they felt initially towards writing in English as well as being able to share their writing-related problems. Studies by Kurt \& Atay's [11] and Yastibas \& Yastibas [27] on 'writing anxiety' in the field of EFL context have mostly focused on the use of peer feedback. In my study, it was found that anxiety was greatly reduced as the collaborative exercise got underway. The participants began to feel increasingly comfortable with each other after receiving motivational phrases (e.g. you're doing well, don't give up, we're with you) and praise (e.g. well done! excellent! good work!) from their team leaders. In addition, informal language, including terms of endearment (e.g. darling, honey and love) and 'text speak' with emoticons along with humour from their peers enabled them to work in a relaxed way when undertaking their individual writing. As explained by the participants, praise motivated them to continue their writing in English especially the giving and receiving of motivational phrases when one of their group partners had difficulties in pursuing a writing task. The findings from this study about reducing anxiety, feeling comfortable and using humour build on the findings of Kurt \& Atay [11] and Yastibas \& Yastibas [27].

Based on the participants' recounting, informal discussions in an online setting, Facebook enabled the participants to feel comfortable with each other when undertaking the writing exercise, and the use of informal language in group discussions (such as they would not normally use out of the Facebook setting) including terms of endearment, the use of texting language and emoticons, and the use of humour when undertaking individual writing tasks. This is I suggest because Facebook is an environment that they use regularly for their social interaction and that affords the support of a culture of emotional support and care and a feeling of being part of a community, supporting the findings of Anderson \& Simpson [1]. Such a culture enabled the students to cope in a very mature way with disputes and concerns that were invariably part of the collaboration. The dimensions of peer collaboration, peer leadership and the associated affective factors lead me to pull together the various strands that created a powerful peer teaching and peer learning environment in this study where the small group unit has been central.

\section{Conclusion}

As reported by the participants, the peer affective factors comprised giving / receiving praise, giving/ receiving motivational phrases, feeling comfortable with each other when undertaking the writing exercise, informal language use in group discussion and the use of humour when undertaking individual writing tasks. According to their comments, feeling comfortable with each other had a positive impact on their writing development, because it reduced apprehension about writing in English and made it 
easier for them to reveal their writing-related problems to their group partners. In addition, receiving praise from their group partners motivated them to write in English and motivational phrases as well as the use of terms of endearment from both group leaders and group partners, helped them increase their self-confidence in engaging in set tasks. Evidence from, for example, participant Ali's accounts shown below reveals the satisfaction and pride the participants felt regarding the outcomes of the collaborative writing exercises. They said that they had found the process enjoyable and their view, and one to which they were entitled to have as the key participants in this study, was that their knowledge of English as well as their ability to write more effectively had improved as a result. As Ali, for example, commented in the final focus group on his feelings of his personal and writing skills development.

"Above all, I had great fun during the writing exercise and noticed and

learnt how the skill of writing could be developed and practised outside the classroom setting. I feel more confident in myself and my writing skills in English” (focus group discussion 4).

I end this paper with what I consider to be a rather insightful quotation from a student who identifies what she perceives as a crucial gap in her experience as a learner, a gap that resonates with the initial motivation for my undertaking this research:

"I really hope that in the near future our teachers understand that students can learn from each other and give more group work exercises, not only in English lessons, but also on other courses" (Ali: focus group discussion, 4).

There are very positive implications for teachers to consider, given restricted time, in incorporating some independent student collaborative writing both in and outside the classroom, for which some Turkish teachers have already expressed considerable enthusiasm as a way to enhance and extend their pedagogical repertoire and learning opportunities for the students.

Acknowledgements: The author would like to would like to express his deepest gratitude to his supervisors, Dr. Jane Jones and Dr. Mary Webb for their generosity, constant encouragement, and valuable advice.

\section{References}

1. Anderson, B., \& Simpson, M.: Group and Class Contexts for Learning and Support Online: Learning and affective support online in small group and class contexts. International Review of Research in Open and Distance Learning, 5(3) (2004).

2. Bani-Hani, N. A., Al-Sobh, M. A., \& Abu-Melhim.: Utilizing Facebook groups in teaching writing: Jordanian EFL students' perceptions and attitudes. International Journal of English Linguistics, 4(5), 27-34 (2014).

3. Chao, Y-C. J. \& Lo, H-C. : Students' perceptions of wiki-based collaborative writing for learners of English as a foreign language. Interactive Learning Environments, 19(4), 395$411(2011)$.

4. Cooper, B. : In search of profound empathy in learning relationships: Understanding the mathematics of moral learning environments. Journal of Moral Education, 39, 79-99 (2010). 
5. Council of Europe : Common European framework of reference for languages: Learning, teaching, assessment. Cambridge: Cambridge University Press (2001).

http://www.coe.int/t/dg4/linguistic/Source/Framework_EN.pdf , accessed 20/06/2017.

6. Dale, H. : Collaborative writing interactions in one ninth-grade classroom. Journal of Education Research, 87, 334-344 (1994).

7. Demirtas, M. : An analysis in purpose to the Facebook and Twitter users in Turkey. British Journal of Arts \& Social Sciences. 9 (2), 116-125 (2012).

8. Hartup, W.W. : Cooperation, close relationships, and cognitive development. In W.M. Bukowski, A.F. Newcomb, \& W.W. Hartup (Eds.), The company they keep: Friendship in childhood and adolescence. (pp. 213-237). New York: Cambridge University Press (1996).

9. Jones, I. \& Pellegrini, A.D. : The effects of social relationship, writing media, and microgenetic development on first grade students' written narratives. American Educational Research Journal, 33, 691-718 (1996).

10. Kessler, G. : Student initiated attention to form in wiki based collaborative writing. Language Learning \& Technology, 13(1), 79-95 (2009).

11. Kurt, G. \& Atay, D. : The effects of peer feedback on the writing of anxiety of prospective EFL teachers, Journal of Theory and Practice in Education, 3, 12-23 (2007).

12. Kutnick, P., Blatchford, P. \& Baines, E. : Grouping of Pupils in Secondary School Classrooms: possible links between pedagogy and learning. Social Psychology of Education, 8(4), 349-374 (2005).

13. Lee, S. C. N. : Written peer feedback by EFL students: praise, criticism and suggestion. Journal of Komaba English Education, 1, 129-139 (2010).

14. Li, M. \& Zhu, W. : Patterns of computer-mediated interaction in small writing groups using wikis. Computer Assisted Language Learning, 26(1), 62-81 (2013).

15. Lin, W.C. \& Yang, S.C. : Exploring students' perceptions of integrating Wiki technology and peer feedback into English writing courses. Teaching: Practice and Critique, 10(2), 88-103 (2011).

16. Lund, A. : Wikis: a collective approach to language production. ReCALL, 20(1), 35-54 (2008).

17. Merriam, S. B. : Qualitative research: A guide to design and implementation. San Francisco: Jossey-Bass (2009).

18. Merriam-Webster's collegiate dictionary: (5th ed.) Springfield, MA: Merriam-Webster (1970).

19. Miyazoe, T. \& Anderson, T. : Learning outcomes and students' perceptions of online writing: Simultaneous implementation of a forum, blog and wiki in an EFL blended learning setting. System, 38, 185-199 (2010).

20. Nguyen, M. H. : EFL students' reflections on peer scaffolding in making a collaborative oral presentation. English Language Teaching, 6(4), pp. 64-73 (2013).

21. Schroeder, R. \& Cahoy, E. S. : Valuing information literacy: Affective learning and the ACRL standards. Portal: Libraries and the Academy, 10(2), 127-146 (2010).

22. Stahl, G.: Group cognition: Computer support for building collaborative knowledge. Cambridge, MA: MIT Press (2006).

23. Storch, N.: Collaborative writing in L2 classrooms: New perspectives on language and education. Bristol, UK: Multilingual Matters (2013).

24. The Turkish Ministry of National Education : Secondary school (grade 9-12) English language teaching curriculum [Ortaoğretim kurumları İngilizce dersi oğretim programi] (2011). https://dyned33.files.wordpress.com/2011/09/ortac3b6c49fretim-ingilizce-dersihazc4b1rlc4b1k-9-12-sc4b1nc4b1flar-c3b6c49fretim-programlarc4b12.pdf, accessed 29/07/2017.

25. Vass, E. : Friendship and collaborative creative writing in the primary classroom. Journal of Computer Assisted Learning, 18(1), 102-110 (2002). 
26. Vygotsky, L. S. Thought and language. Cambridge, Massachusetts: MIT Press (1986).

27. Yastibas, G. C. \& Yastibas, A. E.: The effect of peer feedback on writing anxiety on

Turkish EFL (English as a foreign language) students. Procedia- Social and Behaviour Sciences, 199, 530-538 (2015). 